\title{
Quality indicators of soybean conventional and cross-seeding
}

\section{Indicadores de qualidade da semeadura convencional e cruzada de soja}

\author{
Murilo Aparecido VOLTARELLI'; Rouverson Pereira da SILVA ${ }^{2}$; Cristiano ZERBATO³; \\ Vicente Filho Alves SILVA ${ }^{4}$ Carla Segatto Strini PAIXÃO ${ }^{5}$
}

${ }^{1}$ Autor para correspondência: Eng. Agrônomo; Doutor em Agronomia, UNESP - Universidade Estadual Paulista,
Jaboticabal; murilo_voltarelli@hotmail.com
${ }^{2}$ Eng. Agrícola; Prof. Dr. Livre Docente; UNESP - Universidade Estadual Paulista; rouverson@fcav.unesp.br
${ }^{3}$ Eng. Agrônomo; Doutor em Agronomia; UNESP - Universidade Estadual Paulista; cristianozerbato@hotmail.com
${ }^{4}$ Eng. Agrônomo; Prof. Dr. Auxiliar Adjunto; UFRA - Universidade Federal Rural da Amazônia; vicente.silva@ufra.edu.br
${ }^{5}$ Eng. Agrônomo; Mestre em Agronomia, FCAV UNESP-Jaboticabal; ca_paixão@live.com

Recebido em: 22-05-2014; Aceito em: 28-04-2015

\begin{abstract}
The studies on the spatial arrangement of plants in cross-seeding soybean system are scarce, and then needed to check if this seeding system has higher quality compared to conventional. In this context, the aimed of this study was to evaluate the quality of cross-seeding soybeans compared to conventional, through statistical process control. The experiment was conducted in the agricultural area of Jaboticabal - SP, using a mechanized set tractor-seeder precision with spacing of sowing row set to $0.45 \mathrm{~m}$, and the experimental design completely randomized with 30 repetitions for treatment in conventional sowing and soybean cross. The variables or assessed quality indicators consisted of longitudinal distribution of seeds (normal spacing, defective and double) and final seedling stand. Soybean crop quality indicators are essential to carry out the monitoring of variability and factors that influence the operation. The normal spacing feature is outside the control limits, both for conventional sowing, and for cross-seeding in the main line.
\end{abstract}

Additional keywords: control charts; Glycine max; variability.

\begin{abstract}
Resumo
Estudos sobre o arranjo espacial de plantas em sistema de semeadura cruzada de soja ainda são escassos, sendo então necessários a fim de verificar se este sistema de semeadura apresenta maior qualidade em relação ao convencional. Objetivou-se avaliar a qualidade de semeadura cruzada de soja em relação à convencional, por meio do controle estatístico de processo. O experimento foi conduzido utilizando um conjunto mecanizado trator-semeadora-adubadora de precisão com espaçamento entre fileiras de semeadura reguladas para $0,45 \mathrm{~m}$, com 30 repetições para cada tratamento. As variáveis ou indicadores de qualidade avaliados constituíram-se da distribuição longitudinal das sementes (espaçamentos normais, falhos e duplos) e do estande final de plântulas. Os indicadores de qualidade da semeadura de soja são essenciais para realizar o monitoramento da variabilidade e os fatores que influenciam na operação. Os espaçamentos normais apresentam-se fora dos limites de controle, tanto para a semeadura convencional, quanto para a semeadura cruzada em sua linha principal.
\end{abstract}

Palavras-chave adicionais: cartas de controle; Glycine max.; variabilidade.

\section{Introduction}

The estimated area for soybean crop in Brazil in the $2014 / 2015$ season, for the most part by conventional seeding method, reached $31,334.9$ million hectares, with potential to reach a productivity of $2976 \mathrm{~kg} \mathrm{ha}^{-1}$, which would result in a production of approximately 93,259.9 million Mg (CONAB, 2015). In addition to the conventional seeding, there is the cross-seeding, consisting in the distribution of seeds in parallel rows, as is conventionally performed in soybeans, followed by a new seed distribution on the same area, with the new lines forming angles of $90^{\circ}$ in relation to the previous. Thus, following a recommendation similar to conventional planting system for this crop, there is a doubling of the number of seeds per hectare and the amount of fertilizer applied (Lima et al., 2012), as well as the potential to increase fuel consumption by larger amount of seeded lines.

The soybean crop, in relation to the seeding density, has several studies in the literature, defining those that fit best for certain cultivars, however, studies on spatial arrangement of plants in the area, in cross-seeding system, are still incipient. In practice, cross-seeding is much observed in the area borders, as a compensatory manner, being the environmental conditions in which plants will be developed essential to maximize the expression of the productive potential of the cultivars. Nonetheless, for this to occur, the quality of seeding must be done effectively (Lima et al., 2012). 
Hence, changes related to the population of plants can reduce or increase the gains in productivity because this characteristic is a consequence of the density of plants in the lines and their spacing between the planting rows. However, when the longitudinal distribution of plants is used as seeding quality indicator, being this uneven, it implies an inefficient use of available resources such as light, water and nutrients (Jasper et al., 2011). The increase in population of soybean plants provided by the cross-seeding system has been an important way to provide increased productivity. This productivity increase can be associated with several factors, such as better use of water, due to faster shading of the soil, reducing intraspecific competition, greater ability to compete with weeds and rapid interception of solar energy (Rambo et al., 2003).

In this context, statistical process control aims to quickly detect changes in parameters of certain processes, so that any problems can be detected and subsequently corrected before many non-compliant items are produced or causing the process nonachievement of the expected level of quality (Mingoti \& Fidelis, 2001). With the correction and the elimination of waste and failure, reduction in costs and increased productivity, many benefits will be added to the competitiveness of the field (Bonilla, 1994).

The use of statistical process control to assess and/or monitor quality indicators from mechanized farming operations is still incipient in Brazil, though it is possible to find studies with applications of these tools usually using control charts (individual values and of moving range) in the mechanical harvesting of beans (Silva et al., 2013), coffee (Cassia et al., 2013; Custodio et al., 2012) and sugarcane (Noronha et al., 2011), in the mechanized planting of sugarcane (Voltarelli et al., 2013), and finally in mechanical seeding of peanut (Zerbato et al., 2014).

Assuming that the soybean seeding systems may influence the longitudinal distribution of seeds and the final plant population, it was aimed to evaluate the quality of cross-seeding of soybeans compared to conventional, through quality indicators, using the statistical process control tools.

\section{Material and methods}

The experiment was conducted in the agricultural area of Jaboticabal-SP, in the vicinity of geodetic coordinates $21^{\circ} 14^{\prime}$ latitude South and 48⒈' longitude west, with an average altitude of 595 meters and an average slope of $4 \%$. The soil of the experimental area, which was in the first year of installation of the no-tillage system, is classified as eutroferric Red Latosol, clayey and gently rolling relief, according to Andrioli \& Centurion (1999). The climate of this region is considered to be tropical with summer rains (Aw) by the classification of Köppen-Geiger, with an average temperature of the coldest month exceeding $19^{\circ} \mathrm{C}$, no winter season and rainy summer.
The characterization of the soil water content was carried out before sowing, by collecting 10 samples in 0.00-0.10 m layer according to the methodology recommended by EMBRAPA (1997), in which a percentage of $20 \%$ was verified.

The mechanized set used was a MF660 tractor, 4x2 FWA (front wheel assist), with $110 \mathrm{~kW}$ (150 hp) engine, operated in $3^{\text {rd }} \mathrm{L}$ gear, with a speed of $5.0 \mathrm{~km} \mathrm{~h}^{-1}$, at $1900 \mathrm{rpm}$ in the engine, with the front wheel assist triggered, and a precision seeder-fertilizer of the Marchesan brand, COP Suprema 7/4 model, with vertical pneumatic drive for metering the seeds.

The seeder was equipped for the no-tillage system (double discs mismatched for deposition of seeds and for opening the groove for the deposition of manure - $350 \mathrm{~kg} \mathrm{ha}^{-1}$ fertilizer with 02-20-20 formulation, shank and dual $\mathrm{V}$ seed firming-press wheels were used). The seeder was composed of seven sowing rows with row spacing of $0.45 \mathrm{~m}$, and a working width of $3.15 \mathrm{~m}$. The average depth of deposition of seed and fertilizer was 0.05 to $0.12 \mathrm{~m}$, respectively, which were characterized in eight random sampling points in the experimental area (3.45 ha), measured with the aid of graduated ruler.

The soybean cultivar used was 50615RR $10 \mathrm{sw}$. For the characterization of seeds germination, tests were performed to determine the percentage of germination, which was detected around $70 \%$. This amount obtained is presented below the recommended to soybean crop (90 to $95 \%$ germination), however, in order to avoid failures and damage to the plant arrangement, the seeding density was increased to ensure plant population suitable for culture. It is noteworthy that the manufacturer's recommendation for this cultivar is to use 18 seeds $\mathrm{m}^{-1}$ for conventional seeding system, with the seeds presenting a germination potential of $95 \%$.

The sampling scheme was composed by soybean conventional and cross-seeding systems, containing 30 repetitions or sampling points for each treatment. The statistical method used to monitor the sowing systems quality indicators was the statistical process control, making use of the control charts of individual values and moving range for each indicator. All evaluations were carried out in two rows of plants for both planting systems, in $3.00 \mathrm{~m}$ of evaluation, being the calculations made according to the average sample values, distributed on a sampling grid of $30 \times 20 \mathrm{~m}$.

The quality indicators used to assess the effectiveness of seeding in soybean conventional and cross-seeding systems were: longitudinal distribution between seedlings in the sowing row, determined by classification proposed by Kurachi et al. (1989), based on reference spacing (Xref) according to the regulation of the sower (normal (0.5. Xref $<\mathrm{Xi}<1.5$. Xref), multiple $(X i<0.5$. Xref) and flawed $(X i>1.5 . X$ ref $))$, being the

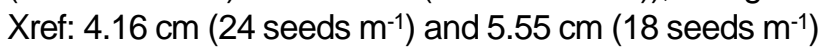
for conventional seeding and for each row of crossseeding, respectively. The desired populations of plants, 
in virtue of the increased seeding density in relation to the recommended by the manufacturer, were 370,000 and 560,000 plants $^{-1} \mathrm{a}^{-1}$ for soybean conventional and crossseeding, respectively.

The final population of plants was measured in the same sample area and subsequently extrapolated to hectare. It is noteworthy that conventional seeding (CS) was performed in a traditional manner. The cross-seeding consisted of distribution of seeds in parallel rows, as is conventionally performed in soybean (CSML - cross-seeding in the main line), followed by new distribution over the same area, with the new lines forming angles of $90^{\circ}$ in relation to the previous (CSCL-cross-seeding that crosses conventional lines), that is, forming a square gride of lines on the crop area.

The control charts of individual and mean amplitude values are constituted basically by the center line, which characterizes the overall average and the average of the moving range, as well as the upper and lower control limits, defined as $\mathrm{UCL}$ and $\mathrm{LCL}$, respectively. The calculations used in the preparation of the control limits for charts of individual values were due to the overall mean and the standard deviation of the variables (for UCL, mean plus three times the standard deviation, and for LCL, average least three times standard deviation) as described by Montgomery (2009), and when the sample values exceed the control limits, the process was considered unstable.
On the other hand, the calculation of the moving range control limits regards the mobile amplitude between two sampling points, in module, multiplied by the number of subgroups. For this study it was defined the number of subgroups as 1 (one). In this sense, the average moving range is calculated through the values that constitute the difference between two consecutive points in module, and when the difference between those points is beyond the control limits it is found that the process potentially has special causes influencing its quality, therefore, it depicts the variation within the sample at a given time instant (Montgomery, 2009). It is emphasized that regardless of the normality assumption, these control charts models were prepared to analyze and detect the intrinsic and extrinsic variability to the process (Samohyl, 2009).

\section{Results and discussions}

By the control charts of individual values for normal spacing (Figure 1a), it is noted the occurrence of a point outside the control limit for both conventional seeding (CS) and cross-seeding in the main line (CSML), showing the instability of the process. Therefore, there is the existence of special causes or external sources of variation acting during the sowing process; these issues should be analyzed, and subsequently removed for future operations in order to achieve the process stability.

(a)

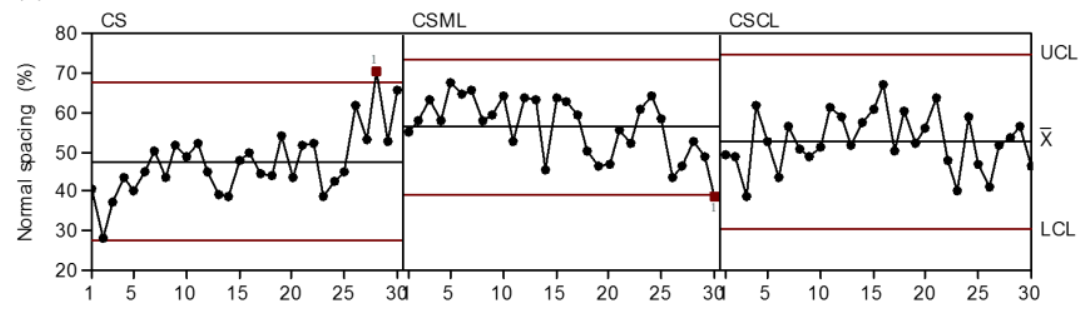

(b)

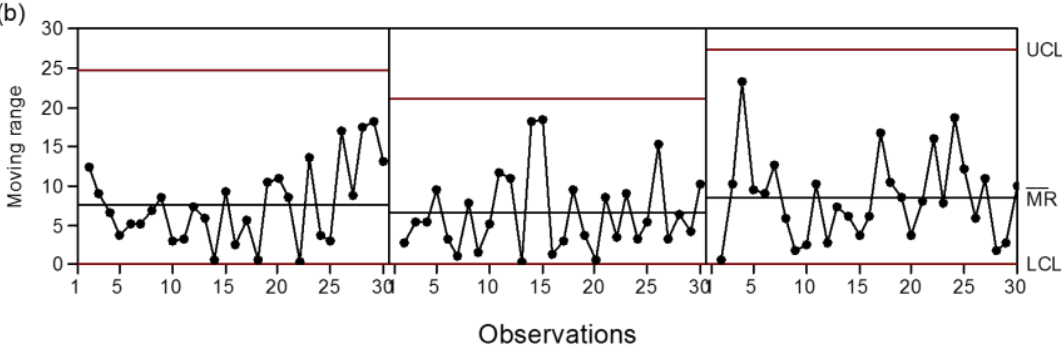

Figure 1 - Control charts for the percentage of normal spacing in soybean conventional and cross-seeding. (a) Chart of individual values. (b) Chart of movable range. UCL: Upper control limit; LCL: Lower control limit; $\bar{X}$ : Average of individual values; $\bar{M} \bar{R}$ : Average of mobile amplitude. CS - Conventional seeding; CSML - Cross-seeding in the main line; CSCL - Cross-seeding in crossing lines.

For conventional seeding, the fact that the point exceeds the upper control limit (note $n^{\circ}$ 28) does not represent a problem, since the greatest amount of normal spacing is favorable for the sowing process. As for the main line of cross-seeding, although a higher average was observed, there was a point beyond the lower control limit (note $n^{\circ} 30$ ), for such the likely reason for its occurrence can be associated with the displacement of seeds in the sowing line when the second step of the operation is performed, when the lines cross, thereby decreasing the occurrence of normal spacing.

Silva et al. (2013) reported that the smaller the variation exists in the course of a given process, the 
better it was the quality with which it was carried out, being this situation extremely favorable to achieve the desired quality standards for mechanized farming operations. This can be accepted for this work, since despite conventional seeding presents unstable process, a higher percentage of normal spacing becomes desirable for soybean seeding, aiming better initial and final stand of plants.

Melo et al. (2013), assessing the distribution of seeds by mechanical and pneumatic seeders, using control charts of the exponentially weighted moving average (EWMA), reported the instability of the seeding process, describing that the inadequate regulation of the seeder resulted in the loss of quality during the operation. This result can be considered as different from the present study, since these results demonstrate the least amount of normal spacing for both cultivation systems.

Contrastively, for the charts of moving amplitude, for all lines of seeding, it can be noted the greater variability in cross-seeding in the crossing line (CSCL), which reflects in lower quality of operation in these sowing lines (Figure 1b). Dias et al. (2009), evaluating the distribution of soybean seeds as a function of seeding density and speed in the conventional system, reported values of approximately 50 and $60 \%$ of normal or acceptable spacing with seeds distribution of 16 and $20 \mathrm{~m}^{-1}$ seed, and working speed of the mechanized set of $5.0 \mathrm{~km} \mathrm{~h}^{-1}$, being these results similar to normal spacing in conventional and cross-seeding systems in this work.

For quality indicator of flawed spacings (Figure 2a), only for the main lines of cross-seeding (CSML) there was a point below the lower control limit (note $n \circ$ 6) to the chart of individual values. However, despite the instability of the process for this quality indicator, a minimum number of points off the lower control limit may be favorable to the operation, because it is the lowest percentage of failures that occur in the seed distribution process. Cortez et al. (2006) studied the conventional mechanized sowing of soybean, through the longitudinal distribution of seeds under no-tillage system, and reported that approximately $24 \%$ had flawed spacings, results much lower when compared to the average obtained in the present work for this quality indicator.

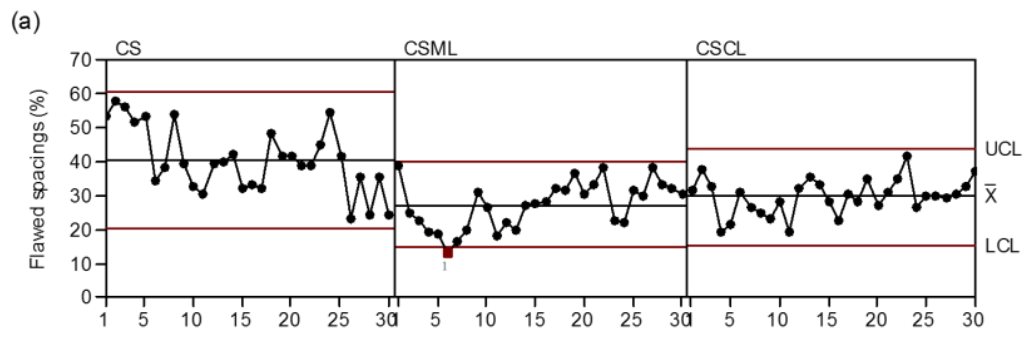

(b)

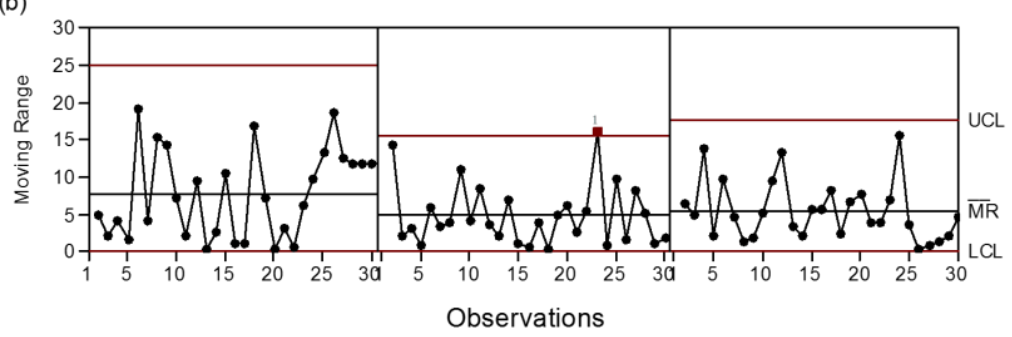

Figure 2 - Control charts for the percentage of flawed spacings in soybean conventional and cross-seeding. (a) Chart of individual values. (b) Chart of movable range. UCL: Upper control limit; LCL: Lower control limit; $\overline{\mathrm{X}}$ : Average of individual values; $\overline{\mathrm{M}} \overline{\mathrm{R}}$ : Average of mobile amplitude. CS - Conventional seeding; CSML - Cross-seeding in the main line; CSCL - Cross-seeding in crossing lines.

By determining the change in the seeding process (Figure $2 \mathrm{~b}$ ), through the charts of moving range, one can observe a point above the upper control limit (note $\mathrm{n}^{\circ}$ 23) for cross-seeding in the main line (CSML), resulting from the highest and lowest variability arising between the notes $n^{\circ} 21$ and 22 from the charts of individual values. It is noteworthy that, even under control, conventional seeding showed greater variability (chart of moving amplitude) and its overall average (chart of individual values) has a higher percentage of flawed spacing, around $40 \%$, compared to crossseeding lines that averaged approximately $30 \%$. This situation can be explained by the fact that the lines intersect in cross-seeding system, with the greatest amount of distributed seeds when compared to the conventional system, having greater potential to avoid increasing the percentage of flawed spacings.

Tourino et al. (2009) reported that the seeders pneumatic systems may favor the reduction of flawed spacing and hence provide conditions for establishing more uniform plant stands, possibly reflecting in increased productivity. This result has contrast with the values obtained in the present study, despite the fact that the seeder-fertilizer also has pneumatic seed suction mechanism, since the percentage of flawed spacings can be considered high for both seeding systems evaluated. 
The double spacing quality indicator, expressed in percentage, was lower for the conventional seeding system compared to the lines of cross-seeding, also presenting the process stability, with all observations or sampling points remaining within the limits of lower and upper control, for both charts of individual values and moving amplitude (Figure $3 a$ and 3b). Such a situation may indicate that the variability for this indicator can only be assigned to common causes (random) of sowing, ie, it is intrinsic to this mechanized operation.

(a)

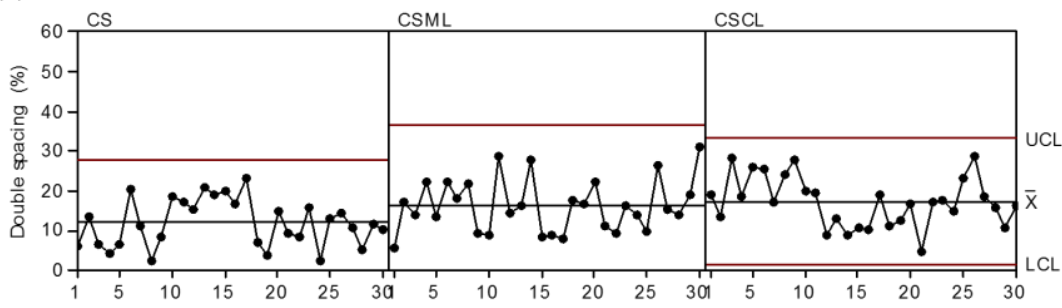

(b)

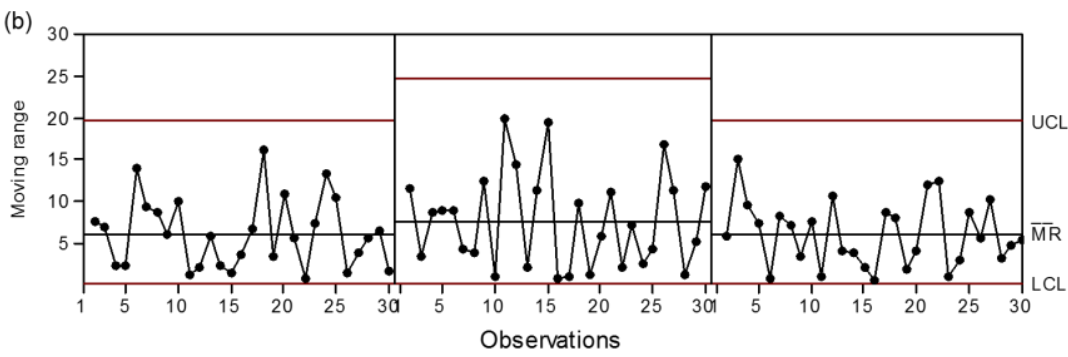

Figure 3 - Control charts for the percentage of double spacing in soybean conventional and cross-seeding. (a) Chart of individual values. (b) Chart of movable range. UCL: Upper control limit; LCL: Lower control limit; $\overline{\mathrm{X}}$ : Average of individual values; $\bar{M} \bar{R}$ : Average of mobile amplitude. CS - Conventional seeding; CSML - Cross-seeding in the main line; CSCL - Cross-seeding in crossing lines.

Toledo et al. (2008) reported that when there is only random causes acting in the course of a given process, being determined by its stability, seeking to reduce or eliminate their sources of intrinsic variations can last for a long time and cause high expenditure of labor hand, possibly being not entirely feasible for the operation. This result is similar to the presented by this study, which also showed only common or random causes for the quality indicator of double spacing, being their values therefore considered acceptable for soybean conventional and cross-seeding.

Regarding the process variation (Figure $3 b$ ), the moving amplitude chart of control showed greater variation in cross-seeding in its main line (CSML) for double spacing, this can be explained by the fact that on this line occurs another perpendicular $\left(90^{\circ}\right)$ passage to complete its spatial arrangement, affecting the spacing of deposition of seeds in the soil. Reis et al. (2007) studied the operational characteristics of a no-tillage seeder-fertilizer in soybeans, using seed dosing perforated discs, and found the lowest percentages of double spacing $(12.8 \%)$ when the tractor-seeder worked at $7.7 \mathrm{~km} \mathrm{~h}^{-1}$, a result similar to that found in this study in which the speed of the mechanized set was 5.0 $\mathrm{km} \mathrm{h}^{-1}$ with use of pneumatic seed metering.

The final plant population, expressed in plants ha-1 ${ }^{-1}$, was stable throughout the operation, for all observations or sampling points remained between the control limits for both the chart of individual values and the moving amplitude ones (Figure $4 a$ and $4 b$ ). However, the cross-seeding system showed the highest variability of the process compared to the conventional (Figure 4b). Such a situation may indicate that the variability arising from this quality indicator can be only attributed to common causes of sowing, and can be somewhat favorable for the operation.

On the other hand, the final population of plants (Figure $4 \mathrm{a}$ ) of the cross-seeding showed both the average (center line) and the distance of the largest control limits in comparison to conventional seeding, pointing, then, greater amount of seeds distributed at the time of sowing, naturally indicating the highest number of plants per hectare in the seeding system. It is noteworthy that the final population of plants found for conventional and cross-seeding were approximately $19 \%$ lower (370,000 plants ha-1) and 5\% higher $(560,000$ plants $\mathrm{ha}^{-1}$ ), respectively, than the expected for this operation, being such variability potentially resulting from the batch of seeds used.

Jasper et al. (2011), studying working speeds in soybean conventional seeding with pneumatic seed feeders, reported average values of the final plant population of 300,000 plants ha- $^{-1}$. These results may be different to those found in the present study, in which the mechanized assembly worked approximately at a speed of $5.0 \mathrm{~km} \mathrm{~h}^{-1}$, resulting in higher final plant stand. 
(a)

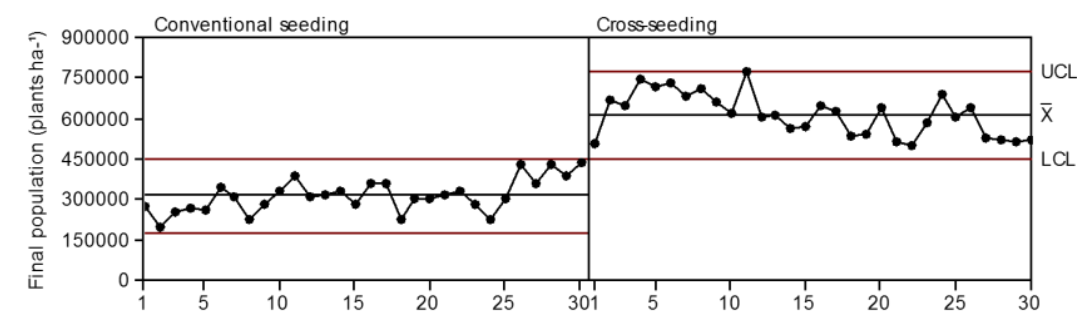

(b)

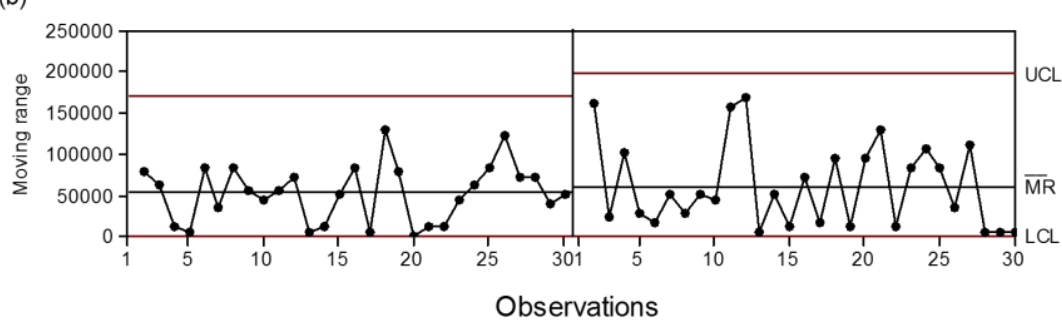

Figure 4 - Control charts for the final population of plants in soybean conventional and cross-seeding. (a) Chart of individual values. (b) Chart of movable range. UCL: Upper control limit; LCL: Lower control limit; $\overline{\mathrm{X}}$ : Average of individual values; $\overline{\mathrm{M}} \overline{\mathrm{R}}$ : Average of mobile amplitude.

\section{Conclusions}

Soybean seeding quality indicators are essential to carry out the monitoring of variability and factors influencing the operation.

The normal spacings featured outside the control limits, both for conventional seeding and for cross-seeding in its main line.

For fail spacing there is greater variability and percentage for conventional seeding, despite the process stability.

\section{References}

Andrioli I, Centurion JF (1999) Levantamento detalhado dos solos da Faculdade de Ciências Agrárias e Veterinárias de Jaboticabal. In: CONGRESSO BRASILEIRO DE CIÊNCIA DO SOLO, 27, 1999, Brasília. Anais... Brasília: Sociedade Brasileira de Ciência do solo. (CD-ROM).

Bonilla JA (1994). Qualidade total na agricultura: fundamentos e aplicações. 2 ed. Belo Horizonte: Centro de Estudos de Qualidade Total na Agricultura. 311p.

Cassia MT, Silva RP, Chioderoli CA, Noronha RHF, Santos EP (2013) Qualidade da colheita mecanizada de café em sistema de plantio circular. Ciência Rural 43(1):28-34. doi: 10.1590/S0103-84782012005000148.

CONAB (2015) Companhia Nacional de Abastecimento. Acompanhamento da safra brasileira de grãos: soja 2(6):74-83 Disponível em: $<$ http://www.conab.gov.br/conteudos.php?a=1253\&>. Acesso em: 10 abr. 2015.

Cortez JW, Furlani CEA, Silva RP, Lopes, A (2006) Distribuição longitudinal de sementes de soja e características físicas do solo no plantio direto. Engenharia Agrícola 26(2):502-510. doi: 10.1590/S0100-69162006000200019.
Custodio AAP, Silva RP, Lemos LB, Toledo A, Lima LP (2012) Controle estatístico aplicado na colheita mecanizada de cafeeiros irrigados. Revista de Agricultura (1):172-180.

Dias OV, Alonço AS, Baumhardt UB, Bonotto JG (2009) Distribuição de sementes de milho e soja em função da velocidade e densidade de semeadura. Ciência Rural 39(6):1721-1728.

doi:

10.1590/S010384782009005000105.

EMBRAPA. (1997) Empresa Brasileira de Pesquisa Agropecúaria. Manual de métodos e análise de solo, 2. ed. Rio de Janeiro: Embrapa. 212 p.

Jasper R, Jasper M, Assumpção PSM, ROCIL J, Garcial C (2011) Velocidade de semeadura da soja. Engenharia Agrícola 31(1):102-110. doi: 10.1590/S0100-69162011000100010.

Kurachi SAH, Costa JAS, Bernardi JÁ, Coelho JLO, Silveira, GM (1989) Avaliação tecnológica de semeadoras e/ou adubadoras: tratamento de dados de ensaios e regularidade de distribuição longitudinal de sementes. Bragantia 48(2):249-62. doi: 10.1590/S0006-87051989000200011.

Lima SF, Alvarez RC, Theodoro GF, Bavaresco M, SILVA KS (2012) Efeito da semeadura em linhas cruzadas sobre a produtividade de grãos e a severidade da ferrugem asiática da soja. Bioscience Journal 28(6):954-962.

Melo RP, Albieiro D, Monteiro LA, Souza FH, Silva JG (2013) Qualidade na distribuição de sementes de milho em semeadoras em um solo cearense. Revista Ciência Agronômica 44(1):94-101.

Mingoti AS, Fidelis MT (2001) Aplicando a geoestatística no controle estatístico de processo. Revista Produto e Produção 5(2):55-70.

Montgomery DC (2009) Introdução ao controle estatístico da qualidade. 4 ed. Rio de Janeiro: LTC. 513p. 
Noronha RHF, Silva RP, Chioderoli CA, Santos EP, Cassia MT (2011) Controle estatístico aplicado ao processo de colheita mecanizada diurna e noturna de cana-de-açúcar. Bragantia 70:1-8. doi: 10.1590/S0006-87052011000400028.

Rambo L, Costa JA, Pires JLF, Parcianello G, Ferreira FG (2003) Rendimento de grãos da soja em função do arranjo de plantas. Ciência Rural 33(3):405-411. doi: 10.1590/S0103-84782003000300003.

Reis EF, Moura JR, Delmond, JG, Cunha JPAR (2007) Características operacionais de uma semeadora-adubadora de plantio direto na cultura da soja (Glycine max (L.) Merril). Revista Ciências Técnicas Agropecuárias 16(3):70-75.

Samohyl RW (2009) Controle estatístico de qualidade. 1 ed. Rio de Janeiro: Elsevier. 352p.

Silva RP, Cassia MT, Voltarelli MA, Compagnon AM, Furlani CEA (2013) Qualidade da colheita mecanizada de feijão (Phaseolus vulgaris) em dois sistemas de preparo do solo. Revista Ciência Agronômica 44(1):61-69. doi: 10.1590/S1806-66902013000100008.
Toledo A, Tabile RA, Silva RP, Furlani CEA , Magalhães SC, Costa BO (2008) Caracterização das perdas e distribuição de cobertura vegetal em colheita mecanizada de soja. Engenharia Agrícola 28(4):710-719, 2008. doi: 10.1590/S010069162008000400011 .

Tourino MCC, Rezende PM, Silva LA, Almeida LGP (2009) Semeadoras-adubadoras em semeadura convencional de soja. Ciência Rural 39(1):245-249. doi: 10.1590/S0103-84782009000100039.

Voltarelli MA, Silva RP, Rosalen DL, Zerbato C, Cassia MT (2013) Quality of performance of the operation of sugarcane mechanized planting in day and night shifts. Australian Journal of Crop Science 7(9):1396-1406.

Zerbato C, Furlani CEA, Voltarelli MA, Bertonha RS, Silva RP (2014) Quality control to seeding systems and densities in peanut crop. Australian Journal of Crop Science 8(6):992-998. 